\title{
A Coursebook Evaluation Research
}

\author{
Yusuf Uyar, M.A. \\ Şaban Çepik, Ph.D. \\ Ali Doğan, Ph.D.c. \\ Duygu Özmen, M.A. \\ Hakan Aydoğan, Ph.D.c. \\ English Language and Literature, Faculty of Education, Zirve University, Gaziantep, Turkey
}

Doi:10.5901/mjss.2014.v5n9p688

\section{Abstract}

This study aims to evaluate the writing coursebook used in the School of Foreign Languages at a university and accordingly suggest writing strategies. One hundred and fifty one students and 81 teachers from School of Foreign Languages at Zirve University participated in the study. Data collection tools were the questionnaires for both students and teachers. The results of the data indicated that the coursebook has more weaknesses than strengths, and suggested writing strategies in order to enhance these weaknesses.

\section{Introduction}

Much has been devoted to teach English as a foreign language all around the world, and thousands of books have been written to facilitate the process of learning a new language. Materials have been developed to give extra assistance to those books whenever needed. However, there are many different walkthroughs serving this purpose, especially producing the language like writing something. Presenting the best and useful material for every individual around the world may be a difficult process, but with a long and planned work, meeting the requirements of any students may be possible.

Students in Turkey do not have a chance to practice English outside the classroom environment. They are not exposed to foreign language, which means lower practice and lower success in development of EFL. Depending on only the books and materials to practice and produce English, students have to get a book that can answer all their needs. For the role of coursebooks, there might be numerous descriptions from all over the EFL authorities. For example, Cook (1998) states that the role of coursebook is how to choose, idealize and understand the language in a simple way to let students access it more often while still going on providing natural input for unconscious acquisition.

Like other Turkish students, the ones in Zirve University School of Foreign Languages have difficulty in producing the language via writing. Many instructors have tried diverse approaches and methods to help them produce better writings whereas few of these have succeeded. Also, every year writing books in each level were undergone a change. With every change it is possible to say that some students find some of these books useful while others think they are totally ineffective. The only result of this may be that books do not appeal all of the students in a class. Some of the students' attention and interest can be high in one activity of pair work, but the others are deaf to this kind of activity. "Factors such as physical layout, design, structure and length will be a key concern both for motivation and for classroom effectiveness" (Jolly \& Bolitho, 1998, p. 282). In order to understand the students and produce the appropriate materials for their needs is very essential in writing classes. In the contrary case, students may have a chance to learn everything in the classroom, but they will fail to produce the language outside the classroom because they are unable to use their productive skills as expected from a language learner. Thus, this study stems from this failure of students in Zirve University in producing and writing something in English.

The aim of this study is to investigate whether the writing book being used in the School of Foreign Languages at Zirve University is appropriate for level $D$ classes regarding their learning needs. Level $D$ is chosen as in this level there are students who passed from $\mathrm{C}$ level and others who have failed in $\mathrm{D}$ level for a long time.

Thus, a wide range of writing tasks, materials and student types can be analyzed. When writing skill is taken into 
consideration, it is clearly seen that learners pay great importance to this skill because this course is usually their only chance to use the language in a productive way.

\section{Research Design}

This study is a quantitative one. In the study the data was collected by means of two different questionnaires and objectives of writing classes in School of Foreign Languages. Those objectives were used to see if the coursebook meets the expectations or not. "Quantitative research is 'explaining phenomena by collecting numerical data that are analyzed using mathematically based methods (in particular statistics)' (Aliaga and Gunderson, 2000).

The first questionnaire administered to the students aimed to see what the students consider about the writing coursebook. The second questionnaire administered to the teachers aimed to obtain the opinions about the writing coursebook. They focus on the problems of producing written materials in EFL classes detected by the researcher who has 5 years of experience and has taken part in testing and assessment of English in the English Program of the university. The researcher used the objectives of writing used in Zirve University School of Foreign Languages. The aim was to see whether the writing book was compatible with the objectives of the English language teaching program of the university and whether it met the needs of the students according to the questionnaires. The findings were analyzed by using descriptive statistics.

\section{Participants}

Our sample consisted of 151 students and 81 teachers. The gender distribution for students subsample is displayed in Figure 1.

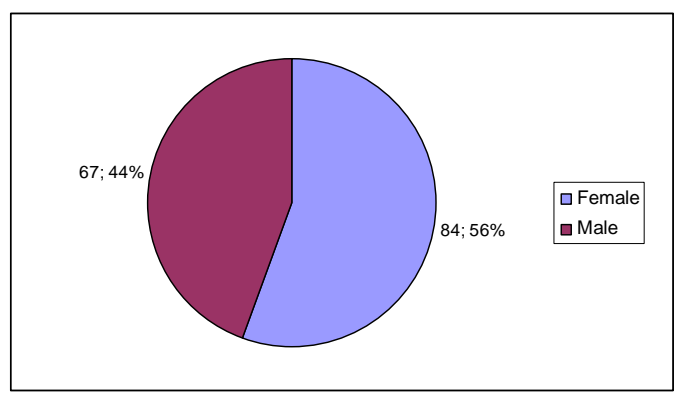

Figure 1. The distribution of gender in the sample of students

As we can see (Figure 1), there were 84 girls ( $56 \%$ of the sample) and 67 boys (44\%).

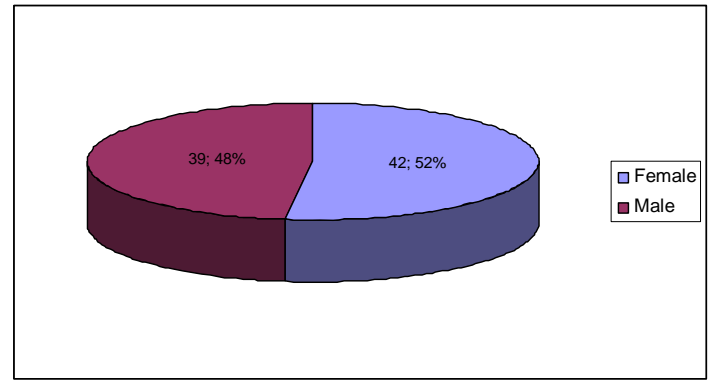

Figure 2. The gender distribution for teachers' subsample

Figure 2 shows us that in our sample of teachers were 42 females ( $52 \%$ of the sample) and 39 males (48\%). 


\section{Results and Discussion}

\subsection{Teachers' questionnaires}

Table 1. Frequencies and percents for items on aim of the coursebook

\begin{tabular}{|c|c|c|c|c|c|c|c|c|c|c|c|c|}
\hline Item number & \multicolumn{2}{|c|}{$\begin{array}{c}\text { totally agree } \\
f \%\end{array}$} & \multicolumn{2}{|c|}{$\begin{array}{c}\text { I agree } \\
f \%\end{array}$} & \multicolumn{2}{|c|}{$\begin{array}{c}\text { I am sure } \\
f \%\end{array}$} & \multicolumn{2}{|c|}{$\begin{array}{c}\text { not I do not agree } \\
\text { f } \%\end{array}$} & \multicolumn{2}{|c|}{$\begin{array}{c}\text { I do not agree at all } \\
f \%\end{array}$} & \multirow{2}{*}{$\begin{array}{c}\mathrm{M} \\
2.90\end{array}$} & \multirow{2}{*}{$\begin{array}{c}\text { SD } \\
1.10\end{array}$} \\
\hline 1. & 6 & 7.4 & 20 & 24.7 & 22 & 27.2 & 26 & 32.1 & 7 & 8.6 & & \\
\hline 2. & 8 & 9.9 & 26 & 32.1 & 24 & 29.6 & 16 & 19.8 & 7 & 8.6 & 3.15 & 1.12 \\
\hline 3. & 8 & 9.9 & 51 & 63.0 & 8 & 9.9 & 14 & 17.3 & 0 & 0.0 & 3.65 & .88 \\
\hline
\end{tabular}

Items:

1. Aim of the coursebook is in accordance with the ELT curriculum and students' aims of learning the language.

2. The coursebook uses effective approaches, methods and techniques to teach English to the university prep students.

3. The coursebook presents its aim clearly to the students and teachers.

As we can see from Table 1, most of participants do not agree that aim of coursebook is in accordance with the ELT curriculum and their aims of learning the language $(n=26$, or $32.1 \%)$. This finding is in accordance with calculated average value of answers on this item $(M=2.90)$, which is below theoretical value (i.e. below 3 ).

Most of our respondents agree that the coursebook uses effective approaches, methods and techniques to teach English to the university prep students $(n=26$, i.e. $32.1 \%$ ). The mean for this item was $M=3.15$, hence, above theoretical average.

The highest number of participants agree that the coursebook presents its aim clearly to the students and teachers $(n=51,63 \%)$, which is also represented as mean of $M=3.65$.

Table 2. Frequencies and percents for items on visual design of the coursebook

\begin{tabular}{|c|c|c|c|c|c|c|c|c|c|c|c|c|}
\hline Item number & \multicolumn{2}{|c|}{$\begin{array}{c}\text { I totally agree } \\
f \%\end{array}$} & \multicolumn{2}{|c|}{$\begin{array}{c}\text { agree } \\
\mathrm{f} \% \\
\end{array}$} & \multicolumn{2}{|c|}{$\begin{array}{c}\text { I am not sure } \\
\text { f } \%\end{array}$} & \multicolumn{2}{|c|}{$\begin{array}{c}\text { I do not agree } \\
\text { f } \%\end{array}$} & \multicolumn{2}{|c|}{$\begin{array}{c}\text { I do not agree at all } \\
\mathrm{f} \%\end{array}$} & \multirow{2}{*}{$\frac{M}{2.36}$} & \multirow{2}{*}{$\begin{array}{l}\text { SD } \\
.66\end{array}$} \\
\hline 4. & 0 & 0.0 & 0 & 0.0 & 37 & 45.7 & 36 & 44.4 & 8 & 9.9 & & \\
\hline 5. & 13 & 16.0 & 42 & 51.9 & 18 & 22.2 & 8 & 9.9 & 0 & 0.0 & 3.74 & .85 \\
\hline 6. & 13 & 16.0 & 34 & 42.0 & 26 & 32.1 & 8 & 9.9 & 0 & 0.0 & 3.64 & .87 \\
\hline 7. & 6 & 7.4 & 26 & 32.1 & 33 & 40.7 & 16 & 19.8 & 0 & 0.0 & 2.48 & .87 \\
\hline
\end{tabular}

Items:

4. The visual design and page layout is suitable and attractive for the university prep students.

5. Printing and the page quality are very good.

6. Style of the scripts, pressing and font size are legible and suitable for the students.

7.Pictures and graphics used in the coursebook are colorful and attractive enough.

37 respondents ( $45.7 \%$ of our sample of teachers) say they are not sure that the visual design and page layout is suitable and attractive for the university prep students. From the mean $(M=2.36)$, we can conclude that there is higher number of students who are not satisfied with this coursebook's features, than those who are.

42 teachers $(51.9 \%)$ agree that printing and the page quality are very good $(M=3.74)$.

Most of teachers (34, i.e. $42.0 \%$ ) agree that style of the scripts, font and pressing are suitable for the students and legible $(M=3.64)$.

Most of our sample $(n=33$, or $40.7 \%$ ) are not sure whether pictures and graphics are colorful and attractive enough. Arithmetic mean for this item shows that there are more teachers who aren't satisfied with pictures in the coursebook $(M=2.48)$. 
Table 3. Frequencies and percents for items on activities and exercises

\begin{tabular}{|c|c|c|c|c|c|c|c|c|c|c|c|c|}
\hline Item number & \multicolumn{2}{|c|}{$\begin{array}{c}\text { I totally agree } \\
\mathrm{f} \%\end{array}$} & \multicolumn{2}{|c|}{$\begin{array}{l}\text { I agree } \\
\mathrm{f} \%\end{array}$} & \multicolumn{2}{|c|}{$\begin{array}{c}\text { I am not sure } \\
\mathrm{f} \%\end{array}$} & \multicolumn{2}{|c|}{$\begin{array}{c}\text { I do not agree } \\
\mathrm{f}\end{array}$} & \multicolumn{2}{|c|}{$\begin{array}{l}\text { I do not agree at all } \\
\mathrm{f} \%\end{array}$} & $\mathrm{M}$ & $\mathrm{SD}$ \\
\hline 8. & 6 & 7.4 & 26 & 32.1 & 33 & 40.7 & 16 & 19.8 & 0 & 0.0 & 3.27 & .87 \\
\hline 9. & 0 & 0.0 & 35 & 43.2 & 30 & 37.0 & 16 & 19.8 & 0 & 0.0 & 3.23 & .76 \\
\hline 10. & 0 & 0.0 & 27 & 33.3 & 38 & 46.9 & 16 & 19.8 & 0 & 0.0 & 3.14 & .72 \\
\hline 11. & 0 & 0.0 & 37 & 45.7 & 12 & 14.8 & 32 & 39.5 & 0 & 0.0 & 3.06 & .93 \\
\hline 12. & 0 & 0.0 & 8 & 9.9 & 37 & 45.7 & 36 & 44.4 & 0 & 0.0 & 2.65 & .65 \\
\hline 13. & 0 & 0.0 & 8 & 9.9 & 19 & 23.5 & 46 & 56.8 & 8 & 9.9 & 2.33 & .79 \\
\hline 14. & 0 & 0.0 & 8 & 9.9 & 35 & 43.2 & 30 & 37.0 & 8 & 9.9 & 2.53 & .81 \\
\hline 15. & 0 & 0.0 & 36 & 44.4 & 17 & 21.0 & 20 & 24.7 & 8 & 9.9 & 3.00 & 1.05 \\
\hline 16. & 8 & 9.9 & 17 & 21.0 & 12 & 14.8 & 36 & 44.4 & 8 & 9.9 & 2.77 & 1.19 \\
\hline 17. & 0 & 0.0 & 43 & 53.1 & 30 & 37.0 & 8 & 9.9 & 0 & 0.0 & 3.43 & .67 \\
\hline 18. & 0 & 0.0 & 65 & 80.2 & 0 & 0.00 & 16 & 19.8 & 0 & 0.0 & 3.60 & .80 \\
\hline 19. & 0 & 0.0 & 42 & 51.9 & 2 & 2.5 & 23 & 28.4 & 14 & 17.3 & 2.89 & 1.22 \\
\hline 20. & 0 & 0.0 & 14 & 17.3 & 16 & 19.8 & 35 & 43.2 & 16 & 19.8 & 2.35 & .99 \\
\hline
\end{tabular}

Items:

8. Activities and exercises are related with the units of the week.

9. The coursebook provides a balance of activities (Ex. There is an even distribution of free vs. controlled exercises and tasks.

10. The coursebook activities can be modified or supplemented easily.

11. Activities and exercises are enough to practice for the students.

12. Activities and exercises are attractive and enjoyable enough for the students' age group.

13. Activities and exercises are helping the students develop the four skills.

14. Activities and exercises appeal to different learning styles and intelligence.

15. Activities and exercises start from easy to hard.

16. Activities and exercises do not require more knowledge or skill than students have.

17. Instructions are clear and easy to follow.

18. The coursebook gives examples before activities and exercises.

19. Activities and Exercises include classroom interaction learning styles like pair work, group work or individual work.

20. To improve the communication skills in foreign language, coursebook includes communicative activities.

Most teachers ( $n=33,40.7 \%$; see Table 3 ) are not sure whether activities and exercises are related with the units of the week or not, but on average, they think that are related $(M=3.27)$.

35 of them (43.2\%) agree that the coursebook provides a balance of activities ( $M=3.23$ ).

38 teachers $(46.9 \%)$ are not sure if the coursebook activities can be modified or supplemented easily, but most of them think that they can $(M=3.14)$.

Most participants $(n=37,45.7 \%)$ agree that activities and exercises are enough to practice for the students (M = $3.06)$, but 37 of them $(45.7 \%)$ are not sure if they're attractive and enjoyable enough for the students' age group (however, $M=2.65$, therefore, more teachers think that they aren't attractive and enjoyable).

Most respondents $(n=46,56.8 \%)$ do not agree that activities and exercises are helping the students to develop the four skills $(M=2.33)$. Most teachers $(35,43.2 \%)$ are not sure whether activities and exercises appeal to different learning styles $(M=2.53$, i.e. most of them think that they aren't).

36 of them $(44.4 \%)$ agree that activities and exercises start from easy to hard $(M=3.00$, i.e. there's equal number of those who think and who didn't think like that).

36 teachers do not agree that these activities and exercises do not require more knowledge or skill than students have $(M=2.77)$.

43 participants $(53.1 \%)$ agree that instructions are clear and easy to follow $(M=3.43)$ and 65 of them $(80.2 \%)$ agree that the coursebook gives examples before activities and exercises.

Most of participants (42, i.e. 51.9\%) agree that these activities/exercises include classroom interaction learning styles (e.g. pair, group and individual work), but $\mathrm{M}=2.89$, so there are lots of them who don't agree or don't agree at all with this item.

Most of teachers $(35,43.2 \%)$ don't agree that coursebook includes communicative activities to improve the communication skills in foreign language $(M=2.35)$. 
Table 4. Frequencies and percents for items on language of the coursebook

\begin{tabular}{|c|c|c|c|c|c|c|c|c|c|c|c|c|}
\hline Item number & \multicolumn{2}{|c|}{$\begin{array}{c}\text { I totally agree } \\
\text { f } \%\end{array}$} & \multicolumn{2}{|c|}{$\begin{array}{c}\text { agree } \\
\mathrm{f} \%\end{array}$} & \multicolumn{2}{|c|}{$\begin{array}{c}\text { I am not sure } \\
f \%\end{array}$} & \multicolumn{2}{|c|}{$\begin{array}{c}\text { d do not agree } \\
f \%\end{array}$} & \multicolumn{2}{|c|}{$\begin{array}{c}\text { I do not agree at all } \\
f \%\end{array}$} & \multirow{2}{*}{$\begin{array}{c}\mathrm{M} \\
2.99\end{array}$} & \multirow{2}{*}{$\begin{array}{r}\text { SD } \\
1.08\end{array}$} \\
\hline 21. & 8 & 9.9 & 14 & 17.3 & 36 & 44.4 & 15 & 18.5 & 8 & 9.9 & & \\
\hline 22. & 0 & 0.0 & 35 & 43.2 & 6 & 7.4 & 24 & 29.6 & 16 & 19.8 & 2.74 & 1.21 \\
\hline
\end{tabular}

Items:

21. The language used in the coursebook is authentic- real life English.

22. The language used in the coursebook is suitable for the students.

Most of teachers $(n=36,44.4 \%)$ are not sure whether the language used in the coursebook is authentic (real life) English $(M=2.99)$, but 35 of them agree that it is suitable for the students (because $M=2.74$, there were lots of them who do not agree and do not agree at all).

Table 5. Frequencies and percents for items on organization and orders of units

\begin{tabular}{|c|c|c|c|c|c|c|c|c|c|c|c|c|}
\hline Item number & \multicolumn{2}{|c|}{$\begin{array}{c}\text { I totally agree } \\
\mathrm{f} \%\end{array}$} & \multicolumn{2}{|c|}{$\begin{array}{c}\text { I agree } \\
\mathrm{f} \%\end{array}$} & \multicolumn{2}{|c|}{$\begin{array}{c}\text { I am not sure } \\
\mathrm{f} \%\end{array}$} & \multicolumn{2}{|c|}{$\begin{array}{c}\text { I do not agree } \\
\mathrm{f} \%\end{array}$} & \multicolumn{2}{|c|}{$\begin{array}{c}\text { d do not agree at all } \\
\mathrm{f} \%\end{array}$} & $\mathrm{M}$ & SD \\
\hline 23. & 0 & 0.0 & 49 & 60.5 & 8 & 9.9 & 16 & 19.8 & 8 & 9.9 & 3.21 & 1.08 \\
\hline 24. & 0 & 0.0 & 41 & 50.6 & 0 & 0.0 & 40 & 49.4 & 0 & 0.0 & 3.01 & 1.01 \\
\hline 25. & 0 & 0.0 & 41 & 50.6 & 24 & 29.6 & 16 & 19.8 & 0 & 0.0 & 3.31 & .78 \\
\hline 26. & 0 & 0.0 & 49 & 60.5 & 16 & 19.8 & 16 & 19.8 & 0 & 0.0 & 3.41 & .80 \\
\hline 27. & 0 & 0.0 & 63 & 77.8 & 16 & 19.8 & 2 & 2.5 & 0 & 0.0 & 3.75 & .49 \\
\hline
\end{tabular}

Items:

23. Organization of the coursebook is clear and easy to follow for the teachers.

24. Organization of the coursebook is clear and easy to follow for the students.

25. The coursebook is user friendly (preface, contents, blank parts for writing etc.)

26. The inner organization of the units is clear and easy to follow.

27. The units have a standard format.

The highest number of teachers agrees with all items of organization and orders of units (from 41 to 63 of them) and all arithmetic means are higher than three (Table 5).

Table 6. Frequencies and percents for items on supporting resources and materials

\begin{tabular}{|c|c|c|c|c|c|c|c|c|c|c|c|c|}
\hline Item number & \multicolumn{2}{|c|}{$\begin{array}{c}\text { I totally agree } \\
\text { f \% }\end{array}$} & \multicolumn{2}{|c|}{$\begin{array}{c}\text { I agree } \\
\mathrm{f} \%\end{array}$} & \multicolumn{2}{|c|}{$\begin{array}{c}\text { I am not sure } \\
\mathrm{f} \%\end{array}$} & \multicolumn{2}{|c|}{$\begin{array}{c}\text { I do not agree } \\
f \%\end{array}$} & \multicolumn{2}{|c|}{$\begin{array}{c}\text { I do not agree at all } \\
\mathrm{f} \% \\
\end{array}$} & \multirow{2}{*}{$\begin{array}{c}M \\
2.75 \\
\end{array}$} & \multirow{2}{*}{$\begin{array}{c}\text { SD } \\
1.16 \\
\end{array}$} \\
\hline 28. & 6 & 7.4 & 14 & 17.3 & 29 & 35.8 & 18 & 22.2 & 14 & 17.3 & & \\
\hline 29. & 6 & 7.4 & 22 & 27.2 & 30 & 37.0 & 7 & 8.6 & 16 & 19.8 & 2.93 & 1.21 \\
\hline
\end{tabular}

Items:

28. Consolidation and revision parts are enough for practice.

29. Teacher's book helps the teacher.

Most of teachers are not sure about supporting resources and materials of the coursebook, but arithmetic means are below three, so lots of them are not satisfied with coursebook as helping tool for teachers (Table 6).

Table 7. Frequencies and percents for items on general evaluations

\begin{tabular}{|c|c|c|c|c|c|c|c|c|c|c|c|c|}
\hline Item number & \multicolumn{2}{|c|}{$\begin{array}{c}\text { I totally agree } \\
\mathrm{f} \%\end{array}$} & \multicolumn{2}{|c|}{$\begin{array}{c}\text { agree } \\
\mathrm{f} \%\end{array}$} & \multicolumn{2}{|c|}{$\begin{array}{c}\text { I am not sure } \\
\mathrm{f} \%\end{array}$} & \multicolumn{2}{|c|}{$\begin{array}{c}\text { d do not agree } \\
\mathrm{f} \%\end{array}$} & \multicolumn{2}{|c|}{$\mathrm{I}$ do not agree at all } & $\mathrm{M} \%$ & $\mathrm{SD}$ \\
\hline 30. & 0 & 0.0 & 29 & 35.8 & 6 & 7.4 & 30 & 37.0 & 16 & 19.8 & 2.59 & 1.17 \\
\hline 31. & 0 & 0.0 & 9 & 11.1 & 8 & 9.9 & 56 & 69.1 & 8 & 9.9 & 2.22 & .77 \\
\hline 32. & 0 & 0.0 & 6 & 7.4 & 14 & 17.3 & 39 & 48.1 & 22 & 27.2 & 2.05 & .86 \\
\hline
\end{tabular}

Items:

30. The coursebook is suitable for the aims of the institution.

31. The coursebook increases the interests of the students.

32. I would use this book again. 
Most of respondents do not agree with items on general evaluations of the coursebook, and this conclusion is supported by the values of arithmetic means ( $\mathrm{M} 1=2.59, \mathrm{M} 2=2.22, \mathrm{M} 3=2.05)$. So, they evaluate this coursebook as unsuitable and not so helpful for students.

\subsection{Students' questionnaires}

Table 8. Frequencies and percents for items on aim of the coursebook

\begin{tabular}{|c|c|c|c|c|c|c|c|c|c|c|c|c|}
\hline Item number & \multicolumn{2}{|c|}{$\begin{array}{c}\text { I totally agree } \\
f \%\end{array}$} & \multicolumn{2}{|c|}{$\begin{array}{c}\text { Iagree } \\
f \%\end{array}$} & \multicolumn{2}{|c|}{$\begin{array}{c}\text { I am not sure } \\
\mathrm{f} \%\end{array}$} & \multicolumn{2}{|c|}{$\begin{array}{c}\text { I do not agree } \\
f \%\end{array}$} & \multicolumn{2}{|c|}{$\begin{array}{c}\text { I do not agree at all } \\
f \%\end{array}$} & \multirow{2}{*}{$\frac{M}{3.09}$} & \multirow{2}{*}{$\frac{S D}{1.29}$} \\
\hline 1. & 20 & 13.2 & 46 & 30.5 & 40 & 26.5 & 18 & 11.9 & 27 & 17.9 & & \\
\hline 2. & 6 & 4.0 & 66 & 43.7 & 41 & 27.2 & 26 & 17.2 & 12 & 7.9 & 3.19 & 1.03 \\
\hline
\end{tabular}

Items:

1.The aim of the book is defined clearly.

2. The aim of the book is suitable for both my school's aims and mine.

Most of students (46, 30.5\%; see Table 8$)$ agree that aim of the book is defined clearly $(M=3.09)$ and is suitable for both purposes ( 66 of them, i.e. $43.7 \%, M=3.19$ ).

Table 9. Frequencies and percents for items on visual design of the coursebook

\begin{tabular}{|c|c|c|c|c|c|c|c|c|c|c|c|c|}
\hline & \multicolumn{2}{|c|}{$\begin{array}{c}\text { I totally agree } \\
f \%\end{array}$} & \multicolumn{2}{|c|}{$\begin{array}{c}\text { I agree } \\
\mathrm{f} \%\end{array}$} & \multicolumn{2}{|c|}{$\begin{array}{c}\text { I am not sure } \\
\mathrm{f} \%\end{array}$} & \multicolumn{2}{|c|}{$\begin{array}{c}\text { I do not agree } \\
\text { f } \%\end{array}$} & \multicolumn{2}{|c|}{$\begin{array}{c}\text { I do not agree at all } \\
\text { f } \%\end{array}$} & \multirow{2}{*}{$\begin{array}{c}M \\
3.41 \\
\end{array}$} & \multirow{2}{*}{$\begin{array}{r}S D \\
1.26 \\
\end{array}$} \\
\hline 3. & 29 & 19.2 & 53 & 35.1 & 43 & 28.5 & 3 & 2.0 & 23 & 15.2 & & \\
\hline 4. & 3 & 2.0 & 47 & 31.1 & 76 & 50.3 & 11 & 7.3 & 14 & 9.3 & 3.09 & .91 \\
\hline
\end{tabular}

Items:

3. The book suits with my level in terms of visuality. (Color, font size etc)

4. The draft and the planning of the book is appropriate and clear enough.

53 participants ( $35.1 \%$ of the sample of students) agree that the book suits with their level in terms of visuality ( $M=3.41$ ), but 76 of them $(50.3 \%)$ is not sure that the draft and the planning of the book is appropriate and clear enough $(M=3.09)$.

Table 10. Frequencies and percents for items on activities and exercises

\begin{tabular}{|c|c|c|c|c|c|c|c|c|c|c|c|c|}
\hline Item number & \multicolumn{2}{|c|}{$\begin{array}{c}\text { I totally agree } \\
\mathrm{f} \%\end{array}$} & \multicolumn{2}{|c|}{$\begin{array}{c}\text { Iagree } \\
\mathrm{f} \%\end{array}$} & \multicolumn{2}{|c|}{$\begin{array}{c}\text { am not sure } \\
\mathrm{f} \%\end{array}$} & \multicolumn{2}{|c|}{$\begin{array}{c}\text { I do not agree } \\
\mathrm{f} \%\end{array}$} & \multicolumn{2}{|c|}{$\begin{array}{c}\text { do not agree at all } \\
\mathrm{f} \%\end{array}$} & $\mathrm{M}$ & SD \\
\hline 5. & 16 & 10.6 & 49 & 32.5 & 34 & 22.5 & 35 & 23.2 & 17 & 11.3 & 3.08 & 1.20 \\
\hline 6. & 9 & 6.0 & 46 & 30.5 & 37 & 24.5 & 37 & 24.5 & 22 & 14.6 & 2.89 & 1.17 \\
\hline 7. & 10 & 6.6 & 38 & 25.2 & 52 & 34.4 & 28 & 18.5 & 23 & 15.2 & 2.89 & 1.14 \\
\hline 8. & 37 & 24.5 & 30 & 19.9 & 32 & 21.2 & 40 & 26.5 & 12 & 7.9 & 3.26 & 1.30 \\
\hline 9. & 25 & 16.6 & 34 & 22.5 & 66 & 43.7 & 14 & 9.3 & 12 & 7.9 & 3.30 & 1.10 \\
\hline 10. & 7 & 4.6 & 62 & 41.1 & 55 & 36.4 & 18 & 11.9 & 9 & 6.0 & 3.26 & .94 \\
\hline 11. & 37 & 24.5 & 34 & 22.5 & 54 & 35.8 & 20 & 13.2 & 6 & 4.0 & 3.50 & 1.12 \\
\hline 12. & 14 & 9.3 & 49 & 32.5 & 71 & 47.0 & 11 & 7.3 & 6 & 4.0 & 3.36 & .90 \\
\hline
\end{tabular}

Items:

5. The activities enable us to make individual, pair and group work.

6. The activities enable us to give creative, authentic and independent answers.

7. The activities are always the same and boring.

8. The activities help me enhance the subjects.

9. I easily understand what should I do with clear instructions in the book.

10. The activities and the exercises in the book are suitable for my level.

11. The book consists activities that help me remember the previous subjects.

12. The activities are balanced. (Free and controlled activities)

Most of students (49, 32.5\%; see Table 10) agree that the activities enable them to make individual, group and pair work $(M=3.08)$ and to give creative, authentic and independent answers $(n=46,30.5 \%$; however $M=2.89$, so lots of them 
disagree or don't agree at all).

52 of them (34.4\%) are not sure if activities are always the same and boring, or not ( $M=2.89$, so more students think that they aren't). 40 students $(26.5 \%)$ don't think that activities help them to enhance the subjects (but most of them think they do, because $M=3.26$ ).

66 students (43.7) are not sure whether they easily understand what they should do with clear instructions in the book (however, more students agree that they easily understand that, because $M=3.30$ ).

Most of participants $(n=62,41.1 \%)$ agree that activities/exercises are suitable for their level $(M=3.26) .54$ of them $(35.8 \%)$ are not sure whether these activities help them to remember the previous subjects, but lots of them think they did help them $(M=3.50)$. 3.36).

71 students (47.0\%) are not sure if the activities are balanced, or not (but most of them think that they are, $M=$

Table 11. Frequencies and percents for items on language of the coursebook

\begin{tabular}{|c|c|c|c|c|c|c|c|c|c|c|c|c|}
\hline Item number & \multicolumn{2}{|c|}{$\begin{array}{c}\text { I totally agree } \\
\mathrm{f} \%\end{array}$} & \multicolumn{2}{c|}{$\begin{array}{c}\text { I agree } \\
\mathrm{f} \%\end{array}$} & \multicolumn{2}{|c|}{$\begin{array}{c}\text { I am not sure } \\
\mathrm{f} \%\end{array}$} & \multicolumn{2}{c|}{$\begin{array}{c}\text { I do not agree } \\
\mathrm{f} \%\end{array}$} & \multicolumn{2}{|c|}{$\begin{array}{c}\text { I not agree at all } \\
\mathrm{f} \%\end{array}$} & $\mathrm{M}$ & $\mathrm{SD}$ \\
\hline 13. & 15 & 9.9 & 55 & 36.4 & 72 & 47.7 & 6 & 4.0 & 3 & 2.0 & 3.48 & .81 \\
\hline 14. & 15 & 9.9 & 38 & 25.2 & 52 & 34.4 & 21 & 13.9 & 25 & 16.6 & 2.98 & 1.21 \\
\hline 15. & 13 & 8.6 & 36 & 23.8 & 54 & 35.8 & 33 & 21.9 & 15 & 9.9 & 2.99 & 1.10 \\
\hline 16. & 12 & 7.9 & 66 & 43.7 & 30 & 19.9 & 28 & 18.5 & 15 & 9.9 & 3.21 & 1.14 \\
\hline 17. & 14 & 9.3 & 54 & 35.8 & 26 & 17.2 & 38 & 25.2 & 19 & 12.6 & 3.04 & 1.22 \\
\hline
\end{tabular}

Items:

13. The subjects are suitable for my needs.

14. The subjects of the materials are interesting and encouraging enough.

15. The subjects are various enough.

16. I think the subjects are interesting and I like them.

17. The subjects are in an order, which go from the easy to the hard ones.

Most of respondents (Table 11) are not sure if the subjects are suitable for them, interesting, encouraging and various enough. But, most students think that the subjects are suitable for their needs $(M=3.48)$. hard ones.

Most of students agree that the subjects are interesting and they like them and that they are in order, from easy to

Table 12. Frequencies and percents for items on organisation and orders of units

\begin{tabular}{|c|c|c|c|c|c|c|c|c|c|c|c|c|}
\hline Item number & \multicolumn{2}{|c|}{$\begin{array}{c}\text { I totally agree } \\
f \%\end{array}$} & \multicolumn{2}{|c|}{$\begin{array}{c}\text { I agree } \\
f \%\end{array}$} & \multicolumn{2}{|c|}{$\begin{array}{c}\text { I am not sure } \\
\mathrm{f} \%\end{array}$} & \multicolumn{2}{|c|}{$\begin{array}{c}\text { I do not agree } \\
f \%\end{array}$} & \multicolumn{2}{|c|}{$\begin{array}{c}\text { I do not agree at all } \\
\mathrm{f} \%\end{array}$} & M & SD \\
\hline 18. & 3 & 2.0 & 62 & 41.1 & 57 & 37.7 & 19 & 12.6 & 10 & 6.6 & 3.19 & .92 \\
\hline 19. & 23 & 15.2 & 42 & 27.8 & 65 & 43.0 & 12 & 7.9 & 9 & 6.0 & 3.38 & 1.03 \\
\hline
\end{tabular}

Items:

18. The language used in the book is compatible with the English used in real life.

19. The language used in the book is suitable with my level of English.

Most of students ( $n=62,41.1 \%$ of the sample; see Table 12) agree that the language used in the book is compatible with the English used in real life $(M=3.19)$. But, most of them $(n=65,43.0 \%)$ are not sure if the language is suitable with their level of English $(M=3.38)$.

Table 13. Frequencies and percents for items on supporting resources and materials

\begin{tabular}{|c|c|c|c|c|c|c|c|c|c|c|c|c|}
\hline Item number & \multicolumn{2}{|c|}{$\begin{array}{c}\text { I totally agree } \\
\mathrm{f} \%\end{array}$} & \multicolumn{2}{|c|}{$\begin{array}{c}\text { I agree } \\
f \%\end{array}$} & \multicolumn{2}{|c|}{$\begin{array}{c}\text { I am not sure } \\
\mathrm{f} \%\end{array}$} & \multicolumn{2}{|c|}{$\begin{array}{c}\text { I do not agree } \\
f \%\end{array}$} & \multicolumn{2}{|c|}{$\begin{array}{c}\text { I do not agree at all } \\
\mathrm{f} \%\end{array}$} & M & SD \\
\hline 20. & 11 & 7.3 & 50 & 33.1 & 49 & 32.5 & 35 & 23.2 & 6 & 4.0 & 3.17 & 1.00 \\
\hline 21. & 18 & 11.9 & 42 & 27.8 & 66 & 43.7 & 9 & 6.0 & 16 & 10.6 & 3.24 & 1.09 \\
\hline
\end{tabular}

Items:

20. Subjects have a standard organization.

21. Order of the subjects (units) is helpful to my learning. 
Most of respondents $(n=50,33.1 \%)$ agree that subjects have a standard organization, but $66(43.7 \%)$ of them are not sure if order of the units is helpful for their learning (however, $M=3.24$, therefore, lots of them agree or totally agree with this item).

Table 14. Frequencies and percents for items on general evaluation

\begin{tabular}{|c|c|c|c|c|c|c|c|c|c|c|c|c|}
\hline & \multicolumn{2}{|c|}{$\begin{array}{c}\text { totally agree } \\
\quad f \%\end{array}$} & \multicolumn{2}{|c|}{$\begin{array}{c}\text { I agree } \\
\mathrm{f} \%\end{array}$} & \multicolumn{2}{|c|}{$\begin{array}{c}\text { I am not sure } \\
f \%\end{array}$} & \multicolumn{2}{|c|}{$\begin{array}{c}\text { I do not agree } \\
\text { f } \%\end{array}$} & \multicolumn{2}{|c|}{$\begin{array}{c}\text { I do not agree at all } \\
\qquad \% \%\end{array}$} & \multirow{2}{*}{$\frac{M}{2.89}$} & \multirow{2}{*}{$\begin{array}{c}\text { SD } \\
.94 \\
\end{array}$} \\
\hline 22. & 0 & 0.0 & 45 & 29.8 & 59 & 39.1 & 33 & 21.9 & 14 & 9.3 & & \\
\hline 23. & 16 & 10.6 & 28 & 18.5 & 52 & 34.4 & 23 & 15.2 & 32 & 21.2 & 2.82 & 1.26 \\
\hline
\end{tabular}

Items:

22. The coursebook encourages me to study English in the future.

23. I would prefer this book if I had to study this level again.

The general evaluation of the coursebook, from the corner of students, is average, because most of them are not sure (don't agree, nor disagree) that the coursebook encourages them to study English in the future and that they would prefer this book if they had to study their level again. By looking the mean values (Table 14), we can say that lots of them do not agree or don't agree at all with items for general evaluation of the coursebook $(M 1=2.89, M 2=2.82$, i.e. both of them are below the theoretical average value 3).

\section{Conclusion}

The purpose of this study was to identify whether the writing coursebook used in School of Foreign Languages at Zirve University meet the needs of the students, the teachers and the institution. The study also aimed to provide writing strategies to help the writing book strengthen the weaknesses determined by the questionnaire 1 and questionnaire 2 . The questionnaires and objectives of writing classes used in the mentioned university were used to reach the findings. The study addressed three research questions.

1. Does the writing book for level D meet the needs of the students at Zirve University?

2. What are the weaknesses and strengths of level $D$ writing book used at Zirve University?

3. What kind of strategies should be used to fill in the gaps in the books, if any?

One hundred and fifty-one students and 81 teachers participated in answering the questionnaires in order to find an answer for the first research question. Mainly the students' answers were used, but those of the teachers also made enormous contributions to the study. The overall implication of the analysis for the first research question might be that the writing coursebook fails to meet the considerable part of the students' needs. Wisniewska (2011) claims in this respect that "no one book can be perfect for a particular institution let alone a particular class within that institution or an individual within a class" (p. 1).

The teachers' questionnaires and the objectives of writing classes in School of Foreign Languages at Zirve University were used to find an answer to the second research question. The identification of the weaknesses and the strengths of the writing coursebook was the focus in Questionnaire 1 and Questionnaire 2. Breen (1989), and Murphy (1985) calls attention to the idea that language-teaching materials should be evaluated in the light of current needs and objectives. Thus questionnaires were of great importance for this study. Hutchinson \& Waters (1987) are for the idea that students' opinions of their needs cannot be underestimated, as students may also have worthy ideas about their own learning, so both students and teachers were required to evaluate the coursebook. Eventually, the results showed that the writing coursebook had some positive aspects; however, the weaknesses went beyond these.

Drawing on the answers for the second research question, some writing strategies to be used in the coursebook were suggested to improve the weak points in an attempt to answer the last research question. However, it is certain that the coursebook cannot be perfect for every student as Cunningsworth (1987) states that there cannot be an excellent coursebook, which meets teachers' and students' all requirements. We can only improve the weak aspects of the coursebooks. Eventually, the results of the questionnaires and the writing skill objectives of the aforementioned institution led the way for these strategies by analyzing the coursebook from three different perspectives, the students', the teachers' and the institution's. 


\section{References}

Aliaga, M., \& Gunderson, B. (2000). Interactive Statistics. NJ: Saddle River.

Allwright, R. (1981). What do we want teaching materials for. ELT Journal , 1.

Amrani, F. (2011). The process of evaluation. In B. Tomlinson, Material development in language teaching (pp. 267-295). Cambridge: Cambridge University Press.

Belcher, D. D. (2006). English for specific purposes: Teaching to perceived needs and imagined futures in worlds of work, study, and everyday life. TESOL Quarterly, 133-156.

Breen, M. (1989). The evaluation cycle for language learning tasks. In R. K. Johnson, The second language curriculum. Cambridge: Cambridge University Press.

Brown, H. D. (1994). Teaching by Principles. New York: Prentice Hall.

Cook, G. (1998). The use of reality: a reply to Ronald Carter. ELT Journal .

Cunningsworth, A. (1995). Choosing your coursebook. oxford: Heienemann.

Cunningsworth, A. (1987). Coursebooks and conversational skills. In L. E. Sheldon, ELT Textbooks and Materials: Problems in Evaluation and Development (p. 7). Oxford: Modern English Publications/The British Council.

Foster, D., \& Russell, B. (2002). Writing and learning in cross-national perspective: Transition from secondary to higher education. In T. Glazier, The least you should know about English writing skills. USA: Harcout Brace College Publishers.

Harding, K. (2007). English for Specific Purposes. Oxford: Oxford University Press.

Hashemian, M., \& Heidari, A. (2013). The relationship between L2 learners' motivation attitude and success in L2 writing. ProcediaSocial and Behavioral Sciences , 476-489.

Hutchinson, T., \& Waters, A. (1987). English for Specific Purposes: A Learning Centered Approach. New York: Cambridge University.

Işık, A. (2011). Language education and ELT materials in Turkey from the path dependence perspective. H. U. Journal of Education , 257.

Jolly, D., \& Bolitho, R. (1998). A framework for materials writing. In B. Tomlinson, Materials development in language teaching (pp. 279294). Cambridge: Cambridge University Press.

Murphy, D. (1985). Evaluation in language teaching: assessment, accountability and awareness. In J. Alderson, Evaluation (pp. 1-17). Oxford: Pergamon.

Tomlinson, B. (2008). Language acquisition and language learning materials. In English Language Teaching Materials (pp. 3-14). London: Continuum.

Uyar,Y. (2014). A study on the evaluation of the writing coursebook and development of writing strategies in a university context. Mersin: Cag University.

Wisniewska, H. (2011). Modern teaching materials: SWOT analysis of an ESP textbook. International conference The future of Education (p. 1). Florence: Pixel.

Zohrabi, M. (2011). Coursebook Development and Evaluation for English for General Purposes Course. English Language Teaching , 214. 